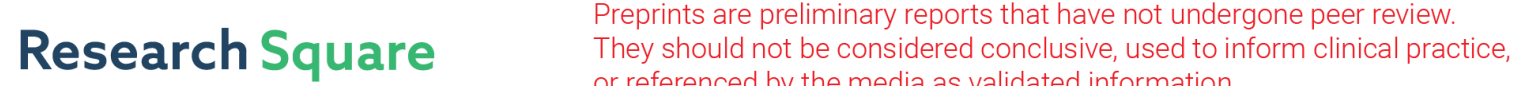 or referenced by the media as validated information. \\ Community Knowledge, Practice and Prevalence of Brucellosis in Livestock owners in Northern Red Sea Region, Eritrea
}

\section{Efrem Ghebremeskel}

National Animal and Plant Health Laboratory

Berhe Tesfai ( $\square$ berhetesfai04@gmail.com)

Ministry of Health, Massawa Hospital

\section{Fitsum Kibreab}

Ministry of Health

\section{Samuel Weldegebriel}

Ministry of Health, Gindae Zonal Referral Hospital

\section{Abraham Dawit}

Ministry of Health, Massawa Hospital

\section{Zemui Mekonen}

Ministry of Health, Massawa Hospital

\section{Hagos Milkyas}

Ministry of Health, Northern Red Sea Region

\section{Esayas Tseghehannes}

Ministry of Health, Gindae Zonal Referral Hospital

Weldeyesus Belay

Ministry of Health, Northern Red Sea Region

\section{Research Article}

Keywords: Brucellosis, Knowledge, Livestock owner, Practice, Prevalence

Posted Date: June 11th, 2021

DOI: https://doi.org/10.21203/rs.3.rs-575361/v1

License: (c) (i) This work is licensed under a Creative Commons Attribution 4.0 International License. Read Full License 


\section{Abstract}

Background: Brucellosis is an infectious zoonotic disease. In the Sub-Saharan Africa, where the prevalence of brucellosis is not clear and the disease has been reported in most parts of Africa including Eritrea. To this date, the level of knowledge and brucellosis status in the livestock owners' of Northern Red Sea region, Eritrea, was unknown. Therefore, the objective of this study was to evaluate the level of knowledge and practice, and determine the prevalence of brucellosis in livestock owners in the Northern Red Sea region, Eritrea.

Methods: It was a descriptive community-based cross-sectional study where villages and households were selected by simple random sampling and systematic random sampling respectively. A total of twenty-nine villages and 22 livestock owners from each village were selected randomly. Blood samples were screened using Rose Bengal plate test and positives further confirmed using competitive enzyme linked immunosorbent assay techniques. Predesigned structured questionnaire was used as data collection tool. A written informed consent was obtained from each study participants. Data were entered into CSPro and analyzed by SPSS software. Results were presented in percent and frequencies.

Results: A total of 637 respondents were enrolled in the study with a mean age of 42.96 . Respondents were dominated by males (74.9\%) and Tigre (73\%) in ethnicity. Majority of them were illiterate $(55.5 \%)$ and $70.5 \%$ were farmers. The overall sero-prevalence of brucellosis in the selected community was found to be $1.8 \%$ with the highest prevalence in Gindae (3.9\%) followed by Shieb (3.6\%) subregion. The comprehensive good knowledge and practice was rated as $58.4 \%$ and $10.5 \%$ respectively. A significant association was also shown with age, ethnicity, religion, level of education, occupation and subregions of the respondents $(p<0.001)$.

Conclusion: The overall sero-prevalence of brucellosis in the livestock owners in the study region was generally low. However, they had lower level of knowledge and very poor practice. Their level of knowledge and practice showed significant association with their age, ethnicity, level of education and sub-regions. Increasing community awareness, introducing Brucella vaccination to animals and strict controlling of selling of unpasteurized milk to the consumers are highly recommended.

\section{Introduction}

The World Health Organization considers brucellosis to be a neglected zoonosis because, despite its widespread distribution and effects on multiple species, it is not prioritized by national and international health systems [1]. Brucellosis is caused by gram-negative bacteria of the genus Brucella which show strong host preference. The most important species of Brucella which infect livestock as their primary hosts are B. melitensis (sheep and goats), B. abortus (cattle), B. suis (pigs) and B. ovis (sheep) [2].

Human brucellosis typically begins as an acute febrile illness with non-specific flu-like signs that can mimic a variety of acute febrile illnesses. Therefore, laboratory tests are essential for accurate diagnosis of the disease. However this in turn presents a particular challenge in laboratory with limited capacity and places where better-known causes of fever, such as malaria or typhoid, co-occur [3].

In most low- and middle-income countries where brucellosis is endemic, physicians diagnose disease using clinical symptoms due to inadequate laboratory facilities. However, Brucellosis shares common clinical symptoms with other diseases such as tuberculosis and malaria in countries where the diseases Loading [MathJax]/jax/output/CommonHTML/jax.js 
are commonly found. This increases the risk of misdiagnosis and wrong treatment leading to potentially worsening of the disease outcomes [4].

Human brucellosis can be prevented through control of animal brucellosis using vaccines, and imposing fastidious hygiene measures on handling and processing of animal products. Effective use of preventive strategies like vaccination programs and education of communities has helped significantly in reducing the prevalence of brucellosis especially in high-income countries [5].

In Eritrea, brucellosis is an important disease in both animals and humans and most human cases appear to be related to the consumption of unpasteurized milk [6]. In cattle, the highest individual seroprevalence was in dairy herds kept under the intensive husbandry system in Asmara, with an individual prevalence of $8.2 \%$ and unit (herd) sero-prevalence of $35.9 \%$. This was followed by $5.0 \%$ individual seroprevalence in the pastoral husbandry system in the Western Lowlands. The lowest was reported in the mixed crop-livestock system in the Southern Highlands with individual $0.3 \%$ and unit (village) prevalence of $2.4 \%[7]$.

In a study of three high-risk occupational groups conducted in Eritrea using Rose Bengal plate and complement fixation tests, the highest prevalence (7.1\%) was found among dairy farm workers/owners followed by veterinary personnel $(4.5 \%)$ and pastoralists $(3,0 \%)$ [8].

Based on the routine work experience and several hospital reports consulted, the prevalence of brucellosis in the community of the Northern Red Sea region was expected to be at higher level while their knowledge and practice on the disease was unknown. Despite the many speculations and reports available, there was no any similar research study conducted on the subject worthy enough to provide valid information for decision making and feasible intervention. Therefore, the aim of this study was to assess the knowledge, practice and determine the prevalence of brucellosis in livestock owners in the Northern Red Sea region. .

\section{Methods}

\section{Study design and sampling}

This study was a descriptive community based cross-sectional type conducted in Northern Red Sea region. Four subregions namely Afabet, Foro, Gindae and Shieb were selected for the study in the region. These four sub-regions were selected considering they are more densely populated with livestock species than the remained six sub regions. Selection of study villages in these subregions was done by simple random sampling technique, after developing a list of all villages keeping livestock species. 
Finally, participant households were selected by systematic random sampling technique from each administrative area and villages. For each selected house hold, the head was responsible to be interviewed with the questionnaire and give blood sample for brucellosis testing.

\section{Sample size calculation}

There was no reliable published literature which indicates the prevalence level of brucellosis in the study area. To obtain the optimum possible sample size for the study, various related standard inputs and sample size adjustment factors were considered as follows: First, an initial sample size was calculated using Epitools online software (https://epitools.ausvet.com.au/prevalencess) assuming imperfect sensitivity and specificity for Rose Bengal plate test (RBPT) and competitive enzyme linked immunosorbent assay (c-ELISA) tests. In view this, the initial sample size was calculated considering 30\% expected prevalence, 95\% confidence level, 0.05 desired precision, 88\% combined sensitivity and 99\% specificity for RBPT and c-ELISA. The combined sensitive and specificity was calculated according to author [9] and the values for RBPT and C-ELISA was obtained from the literature [10]. With this inputs, the epitool software generated an initial sample size of $402\left(n_{1}\right)$. Considering 1.5 between cluster variance the size increased to $603\left(\mathrm{n}_{2}\right)$ and assuming a non-respondent rate of 0.05 the total sample size (Ts) was enlarged to 634 . Secondly a two-stage cluster sampling design was followed as describe by the author [11]. Thus, number of villages to be sampled were calculated using "fixed sample size and unknown clusters" for large populations. Then the sample size was further adjusted using finite population adjustments formula as follows:

$$
\begin{aligned}
g= & \underline{1.96}{ }^{2} \underline{\mathrm{T}}_{\underline{S}} \underline{\mathrm{V}}_{\underline{\mathrm{C}}} \\
& \mathrm{d}^{2} \mathrm{~T}_{\mathrm{S}}-1.96^{2} \mathrm{P}_{\exp }\left(1-\mathrm{P}_{\exp }\right)
\end{aligned}
$$

Where:

$\mathrm{g}=$ number of clusters (villages) to be sampled, $\mathrm{P}_{\exp }=30 \%, \mathrm{~d}=0.05, \mathrm{~T}_{\mathrm{s}}=634, \mathrm{~V}_{\mathrm{C}}=0.04$ (Thrusfield, 2005). Using the above formula and inputs, 124 villages were estimated to be sampled in case of large/infinite population size. However, considering the existing small number of eligible villages in the study area, the number was further adjusted as follows:

g-adj.= Gxg $_{-}, \underline{124 \times 38}=29$ villages

$$
\mathrm{G}+\mathrm{g} \quad 124+38
$$

Finally, the number of livestock owners to be sampled from each selected village (n) was calculated as: $\mathrm{n}=\mathrm{T}_{\mathrm{s}} / \mathrm{g}$-adj, $634 / 29=22$. Thus, a total of 638 (22*29) livestock owners were sampled for blood sample collection and be interviewed using structured questionnaires. Nine, seven, eight and five villages were selected randomly from Afabet, Foro, Gindae and Shieb sub- regions respectively. 


\section{Study population and setting}

Northern Red Sea region has an area size of 34,236 Sq. Km. It has 10 subregions divided into 104 Administrative areas with a total of 289 villages and a total population of 491,657 [12]. Foro sub-region has a total population of 44,444 and 14 administrative area [12]. Gindae sub-region has a population of 58,000 with 5,644 households and Afabet has a population of 91,813 with 14 administrative area and 56 villages. Shieb subregion has a population of 42,600 and 8 administrative area with 15 villages [12]. For this study, a total of 637 individuals were selected and blood samples and questionnaires were collected from each participant.

\section{Inclusion and exclusion criteria}

Farmers who live in the selected community and can properly respond to the questionnaire were included in the study. Farmers aged less than 18 years were excluded from the study. Inhabitants who live in the cities of Foro, Afabet, Shieb and Gindae who live away from farming and grazing animal were excluded from the study, as they are expected to have less contact with animals, their environment and products.

\section{Data collection}

Data and blood collection was conducted from October 22, 2020 to November 10, 2020. Blood was collected by selected and trained laboratory staffs in $10 \mathrm{ml}$ vacutainer tubes from the selected livestock owners. Then serum was separated and stored in refrigerators $\left(0^{\circ} \mathrm{C}-4^{\circ} \mathrm{C}\right)$ and transported in ice boxes covered with cool ice packs to the National Animal and Plant Health Laboratory (NAPHL), Ministry of Agriculture, Asmara for analysis.

Interviewer administered face to face questionnaire was used to evaluate the knowledge and practice of the community on brucellosis. The questionnaire was pretested in the field. The data collection tool was partly adapted from a study by Elisabeth Lindahl et al 2015[13], with slight modification and adjustment to fit the objectives and context of our study. Finally it was translated to local language Tigrigna for the convenience of the data collectors and retranslated back to English to retain its originality. Data collectors were selected based on their linguistic ability as most of the population in the study subregions are Tigre, Saho and Afar ethnic groups. Pilot study was done in neighboring village in order to validate the data collection tool and made necessary adjustment before starting the research in the selected villages.

\section{Blood Sample testing}

Serum samples were tested for Brucella antibodies using RBPT technique as a screening test and all positive results were confirmed using c-ELISA technique. Samples that tested positive on both RBPT and 
c-ELISA were considered to be positive for Brucella. All these laboratory tests were conducted at the National Animal and Plant Health Laboratory, Ministry of Agriculture, Asmara, Eritrea.

\section{Data analysis and interpretation}

Data was entered in CSPro7.2 and analyzed by SPSS software version 21. Results were presented in percent and tables. Statistical analysis with p-value $<0.05$ was used to determine the association of the variables. There were a total of 9 questions of knowledge and 11 questions of practice. Those who respond correctly for each question were given one and zero for those with wrong response. Then results were summed and interpreted as percent. Those who respond greater than $70 \%$ correctly were considered as having good knowledge and practice and those scored with less than $70 \%$ as having poor knowledge and practice respectively.

\section{Ethical consideration}

Ethical clearance was obtained from the Ministry of Health Research and Ethical Review Committee. Confidentiality of the study for participants was secured and written informed consent was requested from each study participants. Local and respected administrators, Ministry of agriculture and Ministry of Health of Northern Red Sea region were also informed before starting the research.

\section{Results}

\section{Socio demographic characteristics and prevalence of brucellosis in the community}

A total of 637 study participants were enrolled in the study with a mean age of 42.96. The respondents were dominated by males (76.3\%) and Tigre (75.4\%) in ethnicity. Majority of the study participants were illiterate (55.0\%) and with primary (26.2\%) level of education. Almost all (97.4\%) of them were Muslim in religion and $70.9 \%$ were farmers. The highest composition of study participants were from Afabet (30.6\%) and Foro (26.4\%) subregions. Two third of the participants were aged between 20 to 60 years.

The sero-prevalence of brucellosis in the selected community of Northern Red Sea region was found to be 1.8\%. The prevalence of brucellosis in livestock owners among the four selected study sub-regions was significantly varied as 3.9\%, 3.64\%, 2.5\% and $0 \%$ in Gindae, Shieb, Afabet and Foro respectively. The 20 to 39 years age group was the most affected age group (2.8\%) and the Rashaida ethnic group was with the largest percentage (5.2\%) affected by the disease. The background of the respondents showed significant association to the prevalence of brucellosis in the community. (Table: 1)

Table 1: Socio demographic characteristics and prevalence of brucellosis

Loading [MathJax]/jax/output/CommonHTML/jax.js 


\begin{tabular}{|c|c|c|c|c|}
\hline Variables & Total $\mathbf{N}(\%)$ & Negative N(\%) & Positive N (\%) & $P$ value \\
\hline \multicolumn{5}{|l|}{ Subzone } \\
\hline Afabet & 199(30.6) & 194(98.3) & $5(1.7)$ & \multirow{4}{*}{$\mathrm{p}<0.001$} \\
\hline Foro & 174(26.4) & 174(100.0) & $0(0.0)$ & \\
\hline Gindae & $154(24.9)$ & 148(96.7) & $6(3.3)$ & \\
\hline Shieb & $110(18.1)$ & 106(97.3) & $4(2.7)$ & \\
\hline \multicolumn{5}{|l|}{ Sex } \\
\hline Male & $477(76.3)$ & $463(97.7)$ & $14(2.3)$ & \multirow[b]{2}{*}{$\mathrm{p}<0.001$} \\
\hline Female & $160(23.7)$ & 159(99.8) & $1(0.2)$ & \\
\hline \multicolumn{5}{|l|}{ Age (years) } \\
\hline$<20$ & $46(7.6)$ & $45(97.7)$ & $1(2.3)$ & \multirow{4}{*}{$\mathrm{p}<0.001$} \\
\hline $20-39$ & $234(35.4)$ & $226(97.2)$ & $8(2.8)$ & \\
\hline $40-59$ & $227(35.1)$ & $222(98.5)$ & $5(1.5)$ & \\
\hline$>=60$ & $130(22.0)$ & 129(99.5) & $1(0.5)$ & \\
\hline \multicolumn{5}{|l|}{ Level of education } \\
\hline Illiterate & $351(55.0)$ & $343(98.3)$ & $8(1.7)$ & \multirow{4}{*}{$\mathrm{p}<0.001$} \\
\hline Primary & $164(26.2)$ & 162(98.9) & $2(1.1)$ & \\
\hline Junior & $56(8.2)$ & 55(99.6) & $1(0.4)$ & \\
\hline Secondary & $62(10.6)$ & $58(94.7)$ & $4(5.3)$ & \\
\hline \multicolumn{5}{|l|}{ Ethnicity } \\
\hline Saho & $141(20.0)$ & 140(99.4) & $1(0.6)$ & \multirow{4}{*}{$\mathrm{p}<0.001$} \\
\hline Tigre & $465(75.4)$ & 452(97.9) & $13(2.1)$ & \\
\hline Tigrigna & $12(2.6)$ & $12(100.0)$ & $0(100.0)$ & \\
\hline Other(Rashaida) & $19(2.0)$ & 18(94.8) & $1(5.2)$ & \\
\hline \multicolumn{5}{|l|}{ Religion } \\
\hline Muslim & $625(97.4)$ & $610(98.1)$ & $15(1.9)$ & \multirow[b]{2}{*}{$\mathrm{p}<0.001$} \\
\hline Christian & $12(2.6)$ & $12(100.0)$ & $0(0.0)$ & \\
\hline \multicolumn{5}{|l|}{ Occupation } \\
\hline Farmer & 449(70.9) & 438(98.0) & $11(2.0)$ & \multirow{3}{*}{$\mathrm{p}<0.001$} \\
\hline Merchant & $8(1.7)$ & $7(93.8)$ & $1(6.2)$ & \\
\hline Other & $180(27.5)$ & 177(98.8) & $3(1.2)$ & \\
\hline Total & $637(100.0)$ & $622(98.2)$ & $15(1.8)$ & \\
\hline
\end{tabular}

\section{Community knowledge and attitude on brucellosis}

Majority of the study participants (73.3\%) had heard the disease brucellosis before and $71.1 \%$ knew that humans can be infected with brucellosis. Two third of the respondents knew that humans can be infected from animals and there is treatment in humans and vaccination in animals. The study participants revealed that; the self-reported prevalence of brucellosis in their life time in the family was $9.4 \%$. Only 8.3\% believed that brucellosis can be cured by local herbs and $66.1 \%$ knew that this disease can be cured by conventional medicine. About half of the study participants reported that all (cows, goats and sheep) 
can get infected with brucellosis and $69.5 \%$ answered that humans can be infected from animals through consumption of raw milk and milk products.

The respondents reported that the main symptoms of brucellosis in humans were joint/back pain (42.9\%) and intermittent fever (14.6\%). They also answered that abortion (26.4\%) and low milk production (10\%) was the main symptoms in animals with brucellosis. Most respondents (76.1\%) believed that their family members are at risk of acquiring brucellosis and they thought that children (36.7\%) were most susceptible to brucellosis. If animal have got brucellosis in their household, majority (64.7\%) had considered it to be very serious. Furthermore, most study participants (97.5\%) need to know information about brucellosis and majority needs to receive the information by health professionals (57.6\%) and community leaders (26.7\%). (Table: 2 )

Table 2: variables for assessment of Knowledge in livestock owners community ( $N=637)$ 


\begin{tabular}{|c|c|c|}
\hline Variables & Frequency (N) & Percent (\%) \\
\hline \multicolumn{3}{|c|}{ Have you heard of the disease Brucellosis? } \\
\hline Yes & 467 & 73.3 \\
\hline No & 170 & 26.7 \\
\hline \multicolumn{3}{|c|}{ Can human be infected with Brucellosis? } \\
\hline Yes & 453 & 71.1 \\
\hline No & 14 & 2.2 \\
\hline \multicolumn{3}{|c|}{ Do you know how humans can be infected from animals? } \\
\hline Yes & 438 & 68.8 \\
\hline No & 29 & 4.6 \\
\hline \multicolumn{3}{|c|}{ Do you know if there is treatment for Brucellosis in humans? } \\
\hline Yes & 425 & 66.7 \\
\hline No & 42 & 6.6 \\
\hline \multicolumn{3}{|c|}{ Do you know if there is vaccination for Brucellosis in animals? } \\
\hline Yes & 393 & 61.7 \\
\hline No & 74 & 11.6 \\
\hline \multicolumn{3}{|c|}{ Has any of your family been diagnosed positive for brucellosis? } \\
\hline Yes & 60 & 9.4 \\
\hline No & 407 & 63.9 \\
\hline \multicolumn{3}{|c|}{ Have any of your animals' diagnosed positive for brucellosis? } \\
\hline Yes & 42 & 6.6 \\
\hline No & 425 & 66.7 \\
\hline \multicolumn{3}{|c|}{ Brucellosis infected humans can be cured by local herbs. } \\
\hline Yes & 53 & 8.3 \\
\hline No & 414 & 65.0 \\
\hline \multicolumn{3}{|c|}{ Brucellosis is transmitted by uncooked meat and/or milk. } \\
\hline Yes & 435 & 68.3 \\
\hline No & 32 & 5.0 \\
\hline \multicolumn{3}{|c|}{ Infected humans can be cured by conventional medicine } \\
\hline Yes & 421 & 66.1 \\
\hline No & 46 & 7.2 \\
\hline \multicolumn{3}{|c|}{ Through which way can humans be infected from animals? } \\
\hline Raw milk and milk product & 443 & 69.5 \\
\hline Placenta and aborted material & 20 & 3.1 \\
\hline Don't know & 126 & 19.8 \\
\hline \multicolumn{3}{|c|}{ What are the main symptoms of brucellosis in human? } \\
\hline Joint/back pain & 273 & 42.9 \\
\hline Intermittent fever & 93 & 14.6 \\
\hline headache & 24 & 3.8 \\
\hline Weakness & 13 & 2.0 \\
\hline \multicolumn{3}{|c|}{ What are the main symptoms of brucellosis in animals? } \\
\hline Abortion & 168 & 26.4 \\
\hline Retained placenta & 28 & 4.4 \\
\hline $\begin{array}{l}\text { Infertilitts } \\
\text { oading [MathJax]/jax/output/CommonHTML/j] }\end{array}$ & 22 & 3.5 \\
\hline
\end{tabular}




\begin{tabular}{|c|c|c|}
\hline low milk production & $\mid 64$ & $\mid 10.0$ \\
\hline \multicolumn{3}{|c|}{ Do you need/would you like to know more information on brucellosis? } \\
\hline Yes & 621 & 97.5 \\
\hline No & 16 & 2.5 \\
\hline \multicolumn{3}{|c|}{ If yes, how would you like to receive the information? } \\
\hline Radio & 85 & 13.2 \\
\hline Community leader & 170 & 26.7 \\
\hline Health professional & 367 & 57.6 \\
\hline
\end{tabular}

\section{Community level of Practice on Brucellosis}

Majority of respondents (78.8\%) wash their hands every time after milking animal. Moreover, most respondents usually feed to dogs (56.2\%) and do nothing (23.5\%) and bury (17.7\%) for an aborted fetus. Majority of the study participants (90.3\%) handle and dispose birth materials and placenta of animals by bare hands, and only $7.1 \%$ wear protective gears to dispose these materials. About half of the study participants (52.4\%) wash their hands to protect themselves when handling placenta or dead fetus. Most respondents seek veterinary assistance (63\%) and report to administrator (26.5\%) if they suspect their animal had brucellosis.

When they buy a new animal, 75\% took an action to assure the animal's health, majority by trusting in their own experience (68.4\%). Only $27.8 \%$ drank fresh milk or yoghurt and $77.8 \%$ didn't boil the milk before selling/using it. For animals with brucellosis, 37.2\% took a measure of slaughtering and 19.6\% used to sell the animal. Two third (77.9\%) of the respondents informed their administrator if they or their animal have the disease brucellosis and $60.1 \%$ used to dump the dung of their animal in specific dumping area. About half of the respondents (58.4\%) have a good comprehensive knowledge but 89.6\% had poor practice on brucellosis. (Table: 3 )

Table 3: Community level of knowledge and Practice on Brucellosis ( $\mathrm{N}=637)$ 


\begin{tabular}{|c|c|c|}
\hline Variables & Frequency (N) & Percent (\%) \\
\hline \multicolumn{3}{|c|}{ How often do you wash your hands after milking your animals? } \\
\hline Every time & 502 & 78.8 \\
\hline Sometimes & 105 & 16.5 \\
\hline Never & 30 & 4.7 \\
\hline \multicolumn{3}{|c|}{ If your answer is "sometime or never"- what is your reason? } \\
\hline Not necessary & 61 & 9.6 \\
\hline No soap & 21 & 3.3 \\
\hline No clean water & 26 & 4.1 \\
\hline Other & 47 & 7.4 \\
\hline \multicolumn{3}{|c|}{ What do you do with aborted fetus? } \\
\hline Feed to dogs & 358 & 56.2 \\
\hline Burn & 16 & 2.5 \\
\hline Do nothing & 150 & 23.5 \\
\hline Bury & 113 & 17.7 \\
\hline \multicolumn{3}{|c|}{ How do you handle and dispose birth materials? } \\
\hline Wearing protective gears & 45 & 7.1 \\
\hline Bare hands & 575 & 90.3 \\
\hline Other & 17 & 2.7 \\
\hline \multicolumn{3}{|c|}{ What do you do to protect yourself from placenta/dead fetuses? } \\
\hline Use gloves & 12 & 1.9 \\
\hline Wash hands & 334 & 52.4 \\
\hline Use nothing & 239 & 37.5 \\
\hline Other & 52 & 8.2 \\
\hline \multicolumn{3}{|c|}{ If you suspect an animal having Brucellosis, what do you do? } \\
\hline Report to administrator & 169 & 26.5 \\
\hline veterinary assistance & 401 & 63.0 \\
\hline Sell it & 14 & 2.2 \\
\hline Slaughter/keep it & 53 & 8.3 \\
\hline \multicolumn{3}{|c|}{ If you buy new animal, do you take actions to assure the animal health? } \\
\hline Yes & 478 & 75.0 \\
\hline No & 159 & 25.0 \\
\hline \multicolumn{3}{|c|}{ Do you drink fresh (raw) milk or yoghurt? } \\
\hline Yes & 177 & 27.8 \\
\hline No & 460 & 72.2 \\
\hline \multicolumn{3}{|c|}{ Do you boil the milk before selling/using it? } \\
\hline Yes & 141 & 22.1 \\
\hline No & 496 & 77.9 \\
\hline \multicolumn{3}{|c|}{ What measures do you take to your animals with brucellosis? } \\
\hline Slaughter it & 237 & 37.2 \\
\hline Sell it & 125 & 19.6 \\
\hline Other & 275 & 43.2 \\
\hline \multicolumn{3}{|c|}{ Did you inform administrator if you have the problem? } \\
\hline ding [MathJax]/jax/output/Com & 496 & 77.9 \\
\hline
\end{tabular}




\begin{tabular}{|l|l|l|} 
No & 141 & 22.1 \\
\hline \multicolumn{2}{|l|}{ Where did you dump the dung of your animals? } \\
\hline Specific dumping area & 383 & 60.1 \\
\hline Leave in house & 120 & 18.8 \\
\hline Other & 134 & 21.0 \\
\hline
\end{tabular}

\section{Association of Comprehensive knowledge and practice to background of participants}

The comprehensive knowledge of the study participants increases with their age ( $p$ value $<0.001$ ).The highest and lowest level of knowledge and practice was reported in Gindae and Shieb sub-regions respectively ( $\mathrm{p}<0.001)$ and the highest good practice $(21.4 \%)$ by sub-region was seen in Gindae subregion ( $p$ <.001). As the level of education increases, the level of knowledge and practice also increases ( $p<0.001$ ). The highest good knowledge and practice was observed in Tigrigna ethnic group and the lowest level of knowledge and practice was observed in the other ethnic group, mostly the Rashaida ( $\mathrm{p}<$ 0.001). All socio demographic characteristics of the study participants showed significant association with their level of knowledge and practice on brucellosis $(\mathrm{p}<0.001)$. (Table 4$)$

Table: 4 Association of Comprehensive knowledge and practice to background of participants 


\begin{tabular}{|c|c|c|c|c|c|c|}
\hline \multirow{3}{*}{ Variables } & \multicolumn{3}{|c|}{ Comprehensive knowledge } & \multicolumn{3}{|c|}{ Comprehensive practice } \\
\hline & \multirow{2}{*}{\begin{tabular}{|l} 
Good \\
$\mathrm{N}(\%)$ \\
\end{tabular}} & \multirow{2}{*}{$\begin{array}{l}\text { Poor } \\
\mathrm{N}(\%)\end{array}$} & \multirow[t]{2}{*}{$P$ value } & Good & Poor & \multirow[t]{2}{*}{$P$ value } \\
\hline & & & & $\mathrm{N}(\%)$ & $\mathrm{N}(\%)$ & \\
\hline \multicolumn{7}{|l|}{ Age(years) } \\
\hline$<20$ & 15(30.9) & $31(69.1)$ & \multirow{4}{*}{$\mathrm{p}<0.001$} & $5(9.6)$ & $41(90.4)$ & \multirow{4}{*}{$\mathrm{p}<0.001$} \\
\hline $20-39$ & $126(51.6)$ & $108(48.4)$ & & $23(10.3)$ & $211(89.7)$ & \\
\hline $40-59$ & 148(67.4) & $79(32.6)$ & & $23(11.8)$ & $204(88.2)$ & \\
\hline$>=60$ & $83(64.4)$ & $47(35.6)$ & & \begin{tabular}{|l}
$15(9.2)$ \\
\end{tabular} & $115(90.8)$ & \\
\hline \multicolumn{7}{|c|}{ Sub regions } \\
\hline Afabet & $140(74.5)$ & $59(25.5)$ & \multirow{4}{*}{$\mathrm{p}<0.001$} & 16(8.9) & 183(91.1) & \multirow{4}{*}{$\mathrm{p}<0.001$} \\
\hline Foro & 96(52.7) & $78(47.3)$ & & $10(5.8)$ & $164(94.2)$ & \\
\hline Gindae & $135(86.4)$ & $19(13.6)$ & & $33(21.9)$ & $121(78.1)$ & \\
\hline Shieb & $1(0.8)$ & $109(99.2)$ & & \begin{tabular}{|l|}
$7(4.6)$ \\
\end{tabular} & 103(95.4) & \\
\hline \multicolumn{7}{|l|}{ Gender } \\
\hline Male & $279(59.7)$ & 198(40.3) & \multirow[b]{2}{*}{$\mathrm{p}<0.001$} & $44(9.3)$ & 433(90.7) & \multirow[b]{2}{*}{$\mathrm{p}<0.001$} \\
\hline Female & 93(54.0) & $67(46.0)$ & & $22(14.4)$ & $138(85.6)$ & \\
\hline \multicolumn{7}{|c|}{ Level of education } \\
\hline Illiterate & 196(56.4) & $155(43.6)$ & \multirow{4}{*}{$\mathrm{p}<0.001$} & $31(9.3)$ & $320(90.7)$ & \multirow{4}{*}{$\mathrm{p}<0.001$} \\
\hline Primary & 93(55.3) & $71(44.7)$ & & 18(11.2) & 146(88.8) & \\
\hline Junior & $34(62.0)$ & $22(38.0)$ & & $8(13.4)$ & $48(86.6)$ & \\
\hline Secondary & $47(74.1)$ & $15(25.9)$ & & $9(13.1)$ & $53(86.9)$ & \\
\hline \multicolumn{7}{|l|}{ Ethnicity } \\
\hline Saho & $100(65.6)$ & $41(34.4)$ & \multirow{4}{*}{$\mathrm{p}<0.001$} & $14(8.8)$ & $127(91.2)$ & \multirow{4}{*}{$\mathrm{p}<0.001$} \\
\hline Tigre & $262(57.2)$ & 203(42.8) & & $47(10.2)$ & $418(89.8)$ & \\
\hline Tigrigna & $10(81.2)$ & $2(18.8)$ & & $5(40.5)$ & $7(59.5)$ & \\
\hline Other & $0(0 \%)$ & 19(100.0) & & $0(0.0)$ & 19(100.0) & \\
\hline \multicolumn{7}{|l|}{ Religion } \\
\hline Muslim & $362(57.8)$ & $263(42.2)$ & \multirow[b]{2}{*}{$\mathrm{p}<0.001$} & $61(9.7)$ & $564(90.3)$ & \multirow[b]{2}{*}{$\mathrm{p}<0.001$} \\
\hline Christian & $10(81.2)$ & $2(18.8)$ & & $5(40.5)$ & $7(59.5)$ & \\
\hline \multicolumn{7}{|l|}{ Occupation } \\
\hline Farmer & $254(57.4)$ & 195(42.6) & \multirow{3}{*}{$\mathrm{p}<0.001$} & $40(9.1)$ & 409(90.9) & \multirow{3}{*}{$\mathrm{p}<0.001$} \\
\hline Merchant & $6(87.3)$ & $2(12.7)$ & & $0(0.0)$ & $8(100.0)$ & \\
\hline Other & $112(59.1)$ & 68(40.9) & & $26(14.7)$ & $154(85.3)$ & \\
\hline Total & $372(58.4)$ & $265(41.6)$ & & $66(10.5)$ & $571(89.5)$ & \\
\hline
\end{tabular}

\section{Discussion}

The objective of this study was to determine the knowledge, practice and estimate the prevalence of brucellosis in livestock owners of Foro, Afabet, Shieb and Gindae sub-regions of Northern Red Sea region. The sero-prevalence of brucellosis in the community was found to be $1.8 \%$. The specific 
prevalence of brucellosis in the community of the subzones was varied with the highest level in Gindae sub-region.

This result was lower compared to a study conducted in Iganga District, Uganda where $4.4 \%$ seropositivity was reported [14]; and rural people in Mongolia, 11.1\%, [15]. The result was also lower compared to the study conducted earlier in Eritrea by Omer (9), in his study the prevalence in the inhabitants in pastoralist areas was (7.1\%) among dairy farm workers and veterinary personnel (4.5\%) [8]. In South Sudan; overall, brucellosis sero-prevalence was 27.2 \% [16] which was much higher than the present study.

The lower level of knowledge and practice on brucellosis, higher illiteracy rate of the farmers and their lower practice on the preventive measures from acquiring the disease could predispose the community to higher prevalence rate. The distribution and variation of the disease in sub-region could be mainly due to the migration and nomadic life style of the livestock owners in Northern Red Sea region.

Majority of the study participants had heard the disease brucellosis before and two third of the respondents knew that humans can be infected from animals and the presence of treatment in humans and vaccination in animals. This was similar to a study conducted in Egypt in that, 83.2\% of the participant had heard of a "disease named brucellosis" and 96.3\% of the participants were correctly answered that brucellosis is transmissible from animals to humans [1]. However in another study reported that $85 \%$ of the farmers had never heard of brucellosis [17]. This high discrepancy of the disease in the community could be mainly due to their level of knowledge and prevalence of the disease e is less pronounced in the community.

According to the respondent's answer; most respondents handle and dispose birth materials and placenta of animals by bare hands. Other study reported that; all participants believed that villagers never wear protective gloves or masks when assisting animals during their parturition or abortion, or handling placenta and aborted fetuses [1]. Their level of knowledge and the improper handling and disposal of the infected materials compounded with not using proper preventive materials is believed that the communities are predisposed to brucellosis and was contributed to increase prevalence of the disease in the community.

Majority of the study participants believed that their family members were at risk of acquiring brucellnsis and thev thnurht that if their animal has got brucellosis, most of them had considered it to be Loading [MathJax]/jax/output/CommonHTML/jax.js 
very serious. Almost all participants of the study were interested to know more information about brucellosis and majority of them preferred to receive the information by health professionals and community leaders. This record was higher compared to other study in that $63 \%$ of the participants wanted more information about brucellosis [13]. This showed that even though they have low level of knowledge and practice, they more interested to further improve their awareness on the subject in turn could have positive contribution towards prevention and control of the disease. Based on the findings, it is believed that by increasing the community's awareness on proper practice of brucellosis, the prevalence of the disease can show dramatic fall within short period of time.

Most of the study participants dispose aborted fetuses and /or fetal membrane by feeding to dogs and leaving in the field, similar to other studies in that $62.5 \%$ fed fetal membranes to dogs and none disinfected abortion sites [18]. But, in the same community their comprehensive good practice was 10.4\%. This could partly show that their level of practice on handling of abortus material was poor, which further risks them to acquire the infection. Thus, we can conclude that even though they have satisfactory level of knowledge, their poor level of practice could further predispose them to brucellosis.

Even though majority of them have the knowledge that brucellosis is transmitted by uncooked meat and/or milk, about one third of the respondents drank fresh milk or yoghurt and most of them didn't boil the milk before selling/using it. This result was similar to other study that; although $92.5 \%$ believed that brucellosis can be transmitted through drinking contaminated milk and had good general knowledge of brucellosis, many participants processed their livestock's milk into cheese and other dairy products without pasteurizing it [1].

Another study also showed that almost 30\% of the households consumed unpasteurized dairy products on regular basis and majority of the respondents did not use any protective gears when handling aborted cows or when dealing with aborted materials [13]. This shows that only knowledge without proper practice is not worthy enough to decrease the rate of transmission of the disease and can't have valuable contribution in reducing the existing prevalence of brucellosis in the community. Thus the health and veterinary professionals should advocate on educating the community to properly apply the correct practice and preventive measures against the disease, hence reduced prevalence of the disease in the community.

Even though the comprehensive knowledge of the respondents was satisfactory, their practice was very poor that only $10.5 \%$ of them had good practice, which needs urgent intervention on the preventive methods and to change the practice of the community on the transmission methods of brucellosis. This study also showed that, the comprehensive good knowledge and practice of brucellosis was significantly associated with age, ethnicity and subregions of the study participants. In Bahr el Ghazal Region of Loading [MathJax]/jax/output/CommonHTML/jax.js 
South Sudan, marital status and ethnicity were associated with brucellosis [16] and other study also reported that low educational level was found to be associated with low awareness of brucellosis [13].

This study showed that the prevalence of brucellosis was slightly higher (2.8\%) among male respondent aged 20 to 39 years. This result was similar to other study in that a high prevalence level of brucellosis (22.8\%) among the participants aged 16-35 years was reported [4]. This could be mainly due to the high exposure and contact of this age group to the animals, animal products and birth materials as family members in this age group are most commonly taking care of their animals and perform all related activities in the communities.

\section{Conclusion}

The livestock owners in the study community had relatively good level of comprehensive knowledge on brucellosis but their level of practice was very low. Most likely, this lower level of practice was directly contributed to the higher sero-prevalence of brucellosis to be increased in the community. Significant difference in sero-prevalence was showed by subregion and villages. Significant association was noticed with age, ethnicity, level of education and sub-region among the study participants

\section{Recommendations}

Increasing the level of awareness about brucellosis in the community by health professionals, community leaders and mass media are very vital and urgent issue. The animals in the study region need to be vaccinated against brucellosis to reduce and stop spreading of the disease to animals and humans. Moreover, movements of animals need to be strictly controlled to limit further spreading of the disease to the other parts of the country. Furthermore, illegals and unsafe milk product sellers must be strictly controlled by the concerned competitive authority. Finally, veterinarians, public health authorities and community leaders need to collaborate and work jointly to control the disease in animals and to manage the risk of human exposure.

\section{Declarations}

\section{Ethical approval and consent to participate}

Approval was obtained from the Ministry of Health Ethical Committee and written consent was obtained from study participants

\section{Consent for publication}

Authors agreed and approved for publication but consent not applicable 
Supplementary data will be available as needed by direct request to the corresponding author

\section{Competing of interest}

Authors declare that they have no any competing interest to disclose.

\section{Funding}

The data collection and laboratory materials were funded by the Ministry of Agriculture, Eritrea and the expenses for the data collectors were covered by the Ministry of health Northern Red Sea Region, Eritrea.

\section{Author's contribution}

The proposal was first designed by BT, FK, SW and EG. Then, all the authors have participated on drafting the final form of the proposal. All authors have participated in supervision and coordinating during data collection. EG analyzed, supervised and coordinated blood sample tests. The sample size and CSPro design was done by FK. Data was entered in CSPro by BT and AD. The SPSS analysis of data was conducted by FK. All authors have contributed by analyzing and interpreting of the results and editing the final form of the manuscript. Finally all authors have read and approved the final form of the manuscript.

\section{Acknowledgment}

Authors acknowledge the Ministry of Agriculture for supplying the data collection materials and for conducting the laboratory analysis. We also acknowledge the Ministry of Health, Northern Rea Sea Region for funding the expense of the data collectors. Finally, we appreciate the heads of the health facilities of the four sub-regions for coordinating and collecting the data.

\section{Abbreviations}

RBPT - Rose Bengal plate test

C-ELISA- competitive enzyme linked immunosorbent assay

CSPro - Census and Survey Processing System

SPSS- Statistical Package for the Social Sciences

NAPHL- National Animal and Plant Health Laboratory

\section{References}

nnah R Holt, Mahmoud M HYPERLINK "https://www.ncbi.nlm.nih.gov/pubmed/? m=Eltholth\%20MM\%5BAuthor\%5D\&cauthor=true\&cauthor_uid=21595871"Eltholth,YamenHYPERLINK 
m=Hegazy\%20YM\%5BAuthor\%5D\&cauthor=true\&cauthor_uid=21595871" M HYPERLINK

tps://www.ncbi.nlm.nih.gov/pubmed/?

m=Hegazy\%20YM\%5BAuthor\%5D\&cauthor=true\&cauthor_uid=21595871"Hegazy, Brucella spp. əction in large ruminants in an endemic area of Egypt: cross-sectional study investigating sero:valence, risk factors and livestock owner's knowledge, attitudes and practices (KAPs). BMC Public alth. 2011; 11:341

rbel MJ, Brinley-Morgan WJ. In: Bergey's manual of systematic bacteriology. Krieg NR HJ, editor. Vol. 1. Itimore, Md: The William and Wilkins Co; 1984. Genus Brucella. Meyer and Shaw 1920, 173AL; pp. 3773.

rcotty, T. et al. Zoonotic tuberculosis and brucellosis in Africa: neglected zoonoses or minor publicllth issues? The outcomes of a multi-disciplinary workshop. Annals of Tropical Medicine \& Parasitology 3, 401-411 (2009).

olHYPERLINK "https://www.ncbi.nlm.nih.gov/pubmed/?

m=Madut\%20NA\%5BAuthor\%5D\&cauthor=true\&cauthor_uid=29949605"HYPERLINK tps://www.ncbi.nlm.nih.gov/pubmed/?

m=Madut\%20NA\%5BAuthor\%5D\&cauthor=true\&cauthor_uid=29949605"AywelHYPERLINK tps://www.ncbi.nlm.nih.gov/pubmed/? m=Madut\%20NA\%5BAuthor\%5D\&cauthor=true\&cauthor_uid=29949605" Madut, George William PERLINK "https://www.ncbi.nlm.nih.gov/pubmed/?

m=Nasinyama\%20GW\%5BAuthor\%5D\&cauthor=true\&cauthor_uid=29949605"Nasinyama, John Bwalya ma, Prevalence of brucellosis among patients attending Wau Hospital, South Sudan. PLoSHYPERLINK e://L:/brucela/5.htm" One. 2018; 13(6): e0199315.

ppas G. Treatment of brucellosis. BMJ. 2008; 336(7646):678-9

bedom, A., Teclebirhan, T., Tekest, T., Zekarias, B., Mufunda, J. \&Gebremichael, A., 2008, 'Recent sons learnt from the outbreak of brucellosis in Dekemhare, Anseba, Eritrea', Journal of the Eritrean dical Association 3, 19-21, viewed 01 December 2011, m http://www.ajol.info/index.php/jema/article/view/49622 MS Excel, 2003, Computer software, srosoft Windows, Redmond, Washington.

ıer, M.K., Skjerve, E., Holstad, G., Woldehiwet, Z. \& Macmillan, A.P., 2000a, 'Prevalence of antibodies to xcella spp. in cattle, sheep, goats, horses and camels in the State of Eritrea; influence of husbandry tems', Epidemiology and Infection 125, 447-453.

K. Omer, T. Assefaw, E. Skjerve, T. Tekleghiorghis and Z. Woldehiwet, Prevalence of Antibodies to ıcella spp. and Risk Factors Related to High-Risk Occupational Groups in Eritrea. Epidemiology and 
ection, Vol. 129, No. 1 (Aug., 2002), pp. 85-91

hoo, L.,Martin,W., Stryhn, H. (2003).Veterinary epidemiologic research. IncJudes index. ISBN 0-9190134, Veterinary epidemiology ResearchTextbooks. I. Dohoo, lan Robert SF780.9.V472003 636.089'44 :003-9045 18-8, P. 27-52

dfroid, J., Nielsen, K. and Saegerman, C. (2010). Diagnosis of Brucellosis in Livestock and Wildlife; Jatian Medi. J. Vol. 51, No. 4, p. 296-305.

rusfield, M.V. (2005). Veterinary Epidemiology. $3^{\text {nd }}$ edition. Oxford. Blackwell Science Ltd, a Blackwell blishing company, P.168-205.

nistry of Health and Ministry of Agriculture, Northern Red Sea Zone, statistics report, 2019

sabeth Lindahl, NosirjonHYPERLINK "https://www.ncbi.nlm.nih.gov/pubmed/?

m=Sattorov\%20N\%5BAuthor\%5D\&cauthor=true\&cauthor_uid=25668783"HYPERLINK

tps://www.ncbi.nlm.nih.gov/pubmed/?

m=Sattorov\%20N\%5BAuthor\%5D\&cauthor=true\&cauthor_uid=25668783"Sattorov, Sofia HYPERLINK tps://www.ncbi.nlm.nih.gov/pubmed/?

m=Boqvist\%20S\%5BAuthor\%5D\&cauthor=true\&cauthor_uid=25668783"Boqvist, Ulf Magnusson. A Idy of Knowledge, Attitudes and Practices Relating to Brucellosis among Small-Scale Dairy Farmers in Urban and Peri-Urban Area of Tajikistan, PLoSHYPERLINK "file://L:/brucela/18.htm" One. 2015; (2): e0117318. doi: 10.1371/journal.pone.0117318

ce Nguna, Michel Dione, Micheal Apamaku, Sero-prevalence of brucellosis and risk factors associated h its seropositivity in cattle, goats and humans in Iganga District, Uganda. The Pan African Medical rnal. 2019; 33:99.

enge Tsend, a Zolzaya Baljinnyam. Sero-prevalence survey of brucellosis among rural people in ngolia. Western Pacific Surveillance and Response Journal, 2014, 5(4). doi:10.5365/wpsar.2014.5.1.002. olHYPERLINK "https://www.ncbi.nlm.nih.gov/pubmed/?

m=Madut\%20NA\%5BAuthor\%5D\&cauthor=true\&cauthor_uid=31297365"HYPERLINK tps://www.ncbi.nlm.nih.gov/pubmed/?

m=Madut\%20NA\%5BAuthor\%5D\&cauthor=true\&cauthor_uid=31297365"AywelHYPERLINK tps://www.ncbi.nlm.nih.gov/pubmed/?

m=Madut\%20NA\%5BAuthor\%5D\&cauthor=true\&cauthor_uid=31297365" Madut, James HYPERLINK tps://www.ncbi.nlm.nih.gov/pubmed/? m=Muleme\%20J\%5BAuthor\%5D\&cauthor=true\&cauthor_uid=31297365"Muleme, CloviceHYPERLINK tps://www.ncbi.nlm.nih.gov/pubmed/? m=Kankva\%20C\%5BAuthor\%5D\&cauthor=true\&cauthor_uid=31297365"HYPERLINK Loading [MathJax]/jax/output/CommonHTML/jax.js 
tps://www.ncbi.nlm.nih.gov/pubmed/?

m=Kankya\%20C\%5BAuthor\%5D\&cauthor=true\&cauthor_uid=31297365"Kankya, The Epidemiology of эnotic Brucellosis in Bahr el Ghazal Region of South Sudan. Front Public Health. 2019; 7: 156

ster G, Osterman BS, Godfroid J, Jacques I, Cloeckaert A. Brucellaceti sp. Nov. And Brucella pinnipedialis Nov. For Brucella strains with cetaceans and seals as their pre-ferred hosts. Int J Syst Evol Microbiol )7; 57:2688-93.

azigaruye, G., Mushonga, B., Kandiwa, E., Samkange, A., Segwagwe, B.E., 2018, 'Prevalence and risk tors for brucellosis seropositivity in cattle in Nyagatare District, Eastern Province, Rwanda', Journal of South African Veterinary Association 89(0), a1625. 